\title{
Correction to: Briquettes of acai seeds: characterization of the biomass and influence of the parameters of production temperature and pressure in the physical-mechanical and energy quality
}

Paulo Renato Souza de Oliveira ${ }^{1} \cdot$ Paulo Fernando Trugilho ${ }^{1} \cdot$ Tiago Jose Pires de Oliveira $^{2}$ (iD

Published online: 27 September 2021

(C) Springer-Verlag GmbH Germany, part of Springer Nature 2021

Correction to: Environmental Science and Pollution Research https://doi.org/10.1007/s11356-021-15847-6

The paper was published in Portuguese.

The Original article has been corrected.

Publisher's note Springer Nature remains neutral with regard to jurisdictional claims in published maps and institutional affiliations.

The online version of the original article can be found at https:/doi.org/ 10.1007/s11356-021-15847-6

\footnotetext{
Tiago Jose Pires de Oliveira tiago.pires@ufla.br

Paulo Renato Souza de Oliveira pr.oliveira0@gmail.com

Paulo Fernando Trugilho trugilho@ufla.br

1 Department of Forest Sciences, Federal University of Lavras, Lavras, MG 37200-000, Brazil

2 Department of Engineering, Federal University of Lavras, Lavras, MG 37200-000, Brazil
} 